\title{
UNIVERSITYOF
}

FORWARD

THINKING

WESTMINSTER用

WestminsterResearch

http://www.westminster.ac.uk/westminsterresearch

The Role of Technical Vocabulary in the Construction of the

Medieval Romance Text Type

Sylvester, L.M.

This is an author's accepted manuscript of an article published in the Journal of English and Germanic Philology, 118 (1), pp. 73-99, 2019.

The final definitive version is available online at:

https://dx.doi.org/10.5406/jenglgermphil.118.1.0073

The WestminsterResearch online digital archive at the University of Westminster aims to make the research output of the University available to a wider audience. Copyright and Moral Rights remain with the authors and/or copyright owners.

Whilst further distribution of specific materials from within this archive is forbidden, you may freely distribute the URL of WestminsterResearch: ((http://westminsterresearch.wmin.ac.uk/)).

In case of abuse or copyright appearing without permission e-mail repository@westminster.ac.uk 


\section{The Role of Technical Vocabulary in the Construction of the Medieval Romance Text Type}

\section{INTRODUCTION}

This paper offers a new approach to the question of how technical language is used in the construction of the romance text type in medieval Britain. ${ }^{1}$ The starting point for this investigation is my impression that the romance text type of the medieval period includes descriptions which seem more detailed than we might expect given the genre and its likely audience. Indeed, it includes a number of poems in which the vocabulary choices suggest a level of precision seeming to amount almost to the appropriation of a technolect for poetic purposes. ${ }^{2}$ We may think of the Gawain-poet's use of terms that precisely distinguish breeds of deer (hi3e for the height of head and antlers, paumes for terminal portions of antlers, brode for extremities of low, wide-slung antlers); and his deployment of the technical term hastlette 3 (pieces of wild pig killed on a nobleman's hunt), which is attested only three times in the corpus of Middle English, in the sections of the poem dealing with the hunt and the treatment of the kill. ${ }^{3}$ Further evidence for the use of precise terminology is provided by the romance Sir Degrevant; see, for example, the description of the bed belonging to its heroine Melidor:

Hur bede was of aszure,

With testur and celure,

With a bryght bordure

Compasyd ful clene.

And all a storye as hyt was

Of Ydoyne and Amadas, 
Perreye in ylke a plas,

And papageyes of grene.

The scochenus of many knyght

Of gold and cyprus was idyght,

Brode besauntus and bryght,

And trewelovus bytwene.

Ther was at hur testere

The kyngus owun banere;

Was nevere bede rychere

Of empryce ne qwene.

Fayr schetus of sylk,

Chalkwhyghth as the mylk,

Quyltus poyned of that ylk,

Touseled they ware;

Coddys of sendal,

Knoppus of crystal

That was mad in Westfal

With women of lare.

Hyt was a mervelous thing

To se the rydalus hyng

With mony a rede gold ryng,

That home upbare.

The cordes that thei on ran

The Duk Betyse hom wan; 
Mayd Medyore hom span

Of meremaydenus hare. (11. 1489-1520) ${ }^{4}$

This depiction includes the place of manufacture of the crystal knobs that decorate the bed (Westphalia), and details about the curtains, the rings that support them (made of 'rede gold'), and the cords on which they run.

Despite the examples referred to above, this precision in the lexis of the romances has not been much noticed by scholars. The romances of medieval England have generally been categorized as somewhat déclassé versions of their continental French ancestors: as a genre, it is 'judged low-class on account of [...] its reliance on stereotypes, formulae and conventional plot structures. ${ }^{5}$ As far as the language is concerned, Derek Pearsall deems the genre to be one of 'formulaic motifs and verbal formulae.' ${ }^{6}$ Nicola McDonald, too, refers to medieval romance's 'formulaic diction.' ${ }^{7}$ These appraisals, all focused on the rather unsophisticated quality of the writing and the likely audiences of the genre, do not notice any particular use of vocabulary that might further our understanding of the construction of the text type and our interpretation of what constitutes technical language in the medieval period.

There are few discussions of the use of technical language in medieval text types and even fewer that are focused on romances. Middle English Word Studies: A Word and Author Index includes summaries of 20 studies that make explicit reference to technical terminology but of these only three concern romances (two discuss the usages in Sir Gawain and the Green Knight noted above; one considers the phrase kan ke dort which appears in Chaucer's Troilus and Criseyde).${ }^{8}$ One possible exception is W. A. Davenport's examination of the

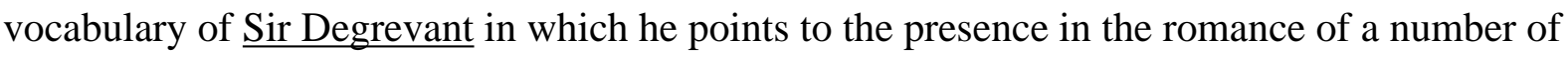
what may be technical terms from fields such as armor and heraldry, castle architecture, and clothing and soft furnishings, noting that many of the lexical items in that romance are 
otherwise recorded only in administrative documents such as wills and inventories. ${ }^{9}$ Again, although the vocabulary is categorized into groups of text types in which the terms appear (literary or administrative), only one text is considered. The paucity of such discussions seems to suggest either that the writers of medieval romances did not deploy technical vocabulary in their works, or that technical terminology is so much a part of what medieval and modern audiences expect in the text type romance that it is not worthy of comment. The latter suggestion is undermined by the fact that almost all the studies of technical vocabulary in medieval literary texts in Middle English Word Studies assume that the use in a literary text of a term or cluster of terms found in works belonging to a particular profession or group (for example, the law, theology or hawking) is remarkable. Some scholars suggest that light may be shed on the writer or the particular usage through reference to the technical sense of a term in cases where a general sense may have been (mistakenly) attributed to its use in the literary text. Others focus on the practice by a particular writer of drawing on or eschewing the vocabulary of a specialized field. These studies point toward a narrative of the relationship between literature and technical language in which literary text types are not expected to draw on vocabulary thought of as part of technical language, so that technical terminology is marked if found in a literary text.

\section{VOCABULARY RELATING TO THE SEMANTIC FIELD OF DRESS AND}

\section{TEXTILES IN THE ROMANCES}

Investigations of historical text types have suggested that they may be identified by 'the correct use of linguistic features obligatory or expected in a specific text type (including the choice of appropriate language and register).' ${ }^{10}$ Technical terminology, the point of interest here, rarely forms part of the discussion about what makes for particularity in medieval text types. In some historical studies the terms 'domain-specific English' and 'discourse-specific 
vocabulary' have been used in place of terms such as 'technical language' or 'language for special purposes' but, as this nomenclature suggests, the tendency in all cases is to nominate a domain that is considered likely to contain technical terminology, and then to examine its lexis, rather than beginning with the lexis and examining its distribution. ${ }^{11}$ Thus, for example, Joanna Bugaj notes that 'Legal and official documents exhibit a lexical range which distinguishes them not only from everyday language but also from other specialized discourses.' 12 This observation, while likely to be true, takes the text type and its vocabulary as given. It does not help us to identify what it is about the language that characterizes less well-delineated text types, and romance is a text type that is notoriously difficult to define. Romance has been described as an abstract category that 'must be envisaged dynamically, as an unending process rather than a rigid set of formal features, ${ }^{, 13}$ and as 'an intriguing, varied, complex and enigmatic corpus so vast and diverse that its potential for interpretation seems limitless.' ${ }^{14}$ We find a cautionary note sounded in the animadversion that genre was not an important concept for medieval theorists, even that the Middle Ages did not have a theoretical conception of genre, and (in particular), that poets did not restrict the romance to a set of characteristics. ${ }^{15} \mathrm{We}$ are also warned that observations about the generic nature of romance must be 'fluid and contingent,' seeking to clarify the nature of single works rather than to classify them. ${ }^{16}$ From the abundance of writing on the medieval romance, however, it is clear that for many scholars it has an existence as a text type. Douglas Kelly, for example, comments on the historical validity of the romance as a genre suggested by 'the medieval use of the word roman and in modern agreement as to which works, by and large, we classify as romance in bibliographies and histories of literature. ${ }^{17}$ Medieval romance was thus understood by contemporary audiences, and is classified by many modern scholars, as a specific text type. What has not been fully examined in discussions of this elusive genre is the contribution of its lexis to the construction of the text type. 
In order to attempt a more thorough investigation of the possible role of technical lexis in the construction of the romance text type, this study focuses on terminology from one semantic field, DRESS AND TEXTILES. Cloth and clothing frequently play an important role in the plots of romances: we may think immediately of the richly worked cloth from which Emaré's robe is made, the baudekine in which the baby Freine is wrapped, which triggers the recognition scene, and Elaine's mistaken belief that Lancelot is in love with her founded on his wearing her sleeve at King Arthur's tournament after telling her that were he to agree to do so 'ye may sey that I do more for youre love than ever y ded for lady or jantillwoman.' 18

\section{II.I DATA AND METHODOLOGY}

This study makes use of the text base assembled for the three-year Leverhulme-funded project Medieval Dress and Textile Vocabulary in Unpublished Sources project and collected in the anthology Medieval Dress and Textiles in Britain: A Multilingual Sourcebook. ${ }^{19}$ The sourcebook is made up of texts and extracts from a variety of medieval text types in Old and Middle English, Latin, and Anglo-French, all produced in Britain and all dealing with dress and textiles. Some of the texts were edited from the manuscripts; in most cases we drew on existing editions. A sub-set of the administrative text types in the text base has been selected for this study. It comprises wills, sumptuary laws, and petitions. These text types are concerned mostly (though not exclusively) with garments and textiles in secular use and thus offer the best alignment with the lexis of the romance. The predominance of religion in the culture of Britain in the medieval period means that many of the other administrative text types included in the anthology contain a considerable amount of vocabulary related to ecclesiastical vestments and items such as altar cloths. ${ }^{20}$ The sourcebook also includes a selection of moral and satirical works inveighing against contemporary fashion, but these do not form a single text type since they consist of sermons, poems and chronicles. 
The selection of the romances for the sourcebook was based on the importance of the role played by cloth and clothing in at least one version of the story. Emaré was chosen because of the robe, described in great detail over almost 100 lines, which appears to have magical properties and certainly determines Emaré's fate on many occasions. This led to the inclusion of other medieval narrations of the story: the Constance story found in the Vitae Offarum Duorum, Nicholas Trevet's Anglo-Norman Life of Constance, and the later Middle English translation 'The Tale of the Wife of Merelaus the Emperor,' Chaucer's ' $\underline{\text { Man of }}$

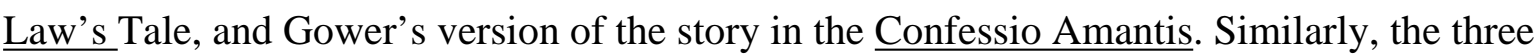
versions of the Launfal story, the Anglo-Norman Lanval, and the Middle English $\underline{\text { Sir }}$

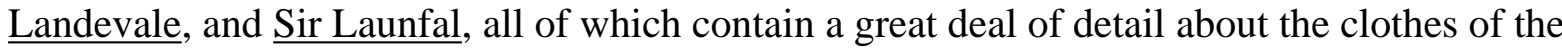
protagonists were included, as were the two versions of the Lai le Fresne. Two romances which feature detailed descriptions of dress and textiles, $\underline{\text { Sir Degrevant and Sir Gawain and }}$ the Green Knight, were also included. The wills were taken from the Furnival's collection of Middle English wills, supplemented by some wills in Latin and Anglo-Norman, and all the sections dealing with cloth and clothing bequests, including household linens, were extracted. Selections were made from the sumptuary laws across the medieval period in England. Similarly, petitions dealing with the dress and textile-related matters, for example, a petition on behalf of a group of children in Edward II's wardship for their clothing allowance was chosen, as was a petition put forward by the weavers of York to Edward III and his council demanding restrictions on the right to make striped and colored cloth outside York. The total word counts for the chosen text types are roughly but not entirely evenly balanced: the excerpts from the romances total 8,116 words, the wills consist of approximately 6,289 words, the sumptuary legislation of 7,189 words, and the petitions only consist of 2,781 words (this discrepancy is because of the extra work involved in transcribing and editing these texts from the manuscript sources). 
In order to compare the distribution of the vocabulary, and to keep the data to a manageable amount in this study, the nouns falling within the semantic field of DRESS AND TEXTILES have been extracted from the four text types according to the following criteria: (i) Terms which appear in at least one of the administrative text types, but not the romances; (ii) Terms which appear in the romances but not the administrative text types. ${ }^{21}$ Only the terms uniquely occurring in each set of text types were selected on the grounds that the most commonly occurring terms are likely to be the least technical; that is, to be terms whose meaning is most general, or perhaps most flexible and adaptable. ${ }^{22}$ There are 200 nouns signifying cloth and clothing in the administrative text types and 82 in the romances, thus there are more than double the number of lexical items in the first category (terms unique to the administrative text types) compared to the number in the second (terms unique to the romances).$^{23}$ It should be noted that some terms are polysemous: they appear in more than one place in the semantic classification and so are counted more than once. For example, blanket (and its variants) signifies 'a woollen cloth, usually white or left undyed, or a piece of such material' in earlier uses of the term, while later uses specify 'a bedspread or covering.' ${ }^{24}$ The figures suggest that the romance text type may contain a slightly wider range of terms than the other text types when the vocabulary from one specific semantic field is examined but they are not conclusive.

In her examination of the vocabulary choices in administrative documents of the late eleventh to the sixteenth centuries, Laura Wright argues that the idea of technicality entails restriction of meaning, and so greater specificity of sense is equated with a greater degree of technicality. ${ }^{25}$ Semantic hierarchies allow us to see how much vocabulary there is at the different levels of specificity of meaning for each text type, and also how many subcategories and sub-groups the lexis of the text types falls into. In order to have a principled definition of technicality in the lexis of medieval texts with which to conduct the analyses of the 
distribution of the vocabulary, I classify the vocabulary into semantic hierarchies, making use of the hyponymy relation ( $\mathrm{x}$ is a kind of $\mathrm{y}$ ). ${ }^{26}$ Analysis of a semantic hierarchy begins with the most general terms (such as plant in a botanical taxonomy) and proceeds downwards. We

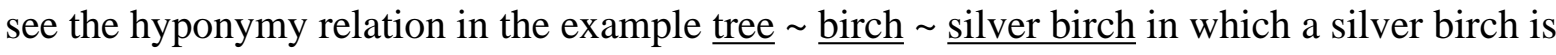
a kind of birch, and a birch is a kind of tree. The methodology is based on componential analysis. Essentially this involves stripping down the meaning of an idea to its basic components, those attributes which distinguish it from any other idea. A classification is created by adding components of meaning, as few as possible at a time, so that a hierachical picture of the semantic category is built up, the meaning of each additional lexical item or group of items being entailed by the meaning of the headword or the group whose meaning is considered central to that category. It is generally recognized that semantic classifications are to some extent subjective; as is owned by, among others, David Sankoff et al:

The basic ethnosemantic tool [...] is a speaker's judgment of specific/generic relationships among terms referring to a class of entities or objects. From statements of the type $\mathrm{X}$ is a special type of $\mathrm{Y} \ldots$ or similar statements where 'special type' is replaced by 'subcategory', 'part of', 'aspect of', and so on, we may infer, in a logical way, a hierarchical structuring of the terms such as a taxonomic tree. ${ }^{27}$

It is also recognized, however, that while there are always possible alternative classifications, patterns emerge from the data, which is generally the dictionaries' definitions of the lexical items. A component of meaning is added at each level, and as we proceed down the hierarchy the terms become more and more precise in their meanings. An example from the vocabulary of the romances is provided by the following sub-group (translations are included here for clarity): 


\author{
.Bedding (general) \\ gerez, geyr, gere (bedclothes)
}

\author{
..Parts of a bed/ bedclothes (specific)

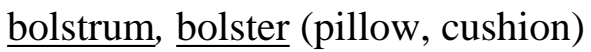 \\ coddys (pillows, cushions) \\ queldepoyntes quilted coverlets \\ quyltus (quilts stuffed with down, etc., used as a mattress, cushion, or coverlet) \\ $\underline{\text { rudelez, rydalus (curtains for a bed) }}{ }^{28}$
}

We can begin to examine and analyse the vocabulary of the romances as compared with that found in the administrative documents by investigating (1) what proportion of the vocabulary comprises general terms for cloth, clothing and accessories, and what proportion consists of terms for specific textiles, garments and accessories in the two categories, romances and administrative text types; (2) how many subcategories and sub-groups the vocabulary of the romances falls into, compared with the number of subcategories and subgroups in the lexis of the administrative text types, and how many items are found at different levels of the semantic hierarchy in the two groupings.

\title{
III. RESULTS AND DISCUSSION
}

\section{III.I GENERAL TERMS FOR CLOTH, CLOTHING AND ACCESSORIES}

The proportions of the general terms for cloth, clothing, and accessories across the two categories are a little different. The administrative text types have one term below the 
subcategory headword Cloth, pannus (and variants), which appears in a wide variety of the administrative text types, and which means both 'cloth' and 'clothing.' ${ }^{29}$ The romances also contain one term below the headword Cloth, bofu; this term is less general than the one found in the administrative documents, as it only has the sense 'fabric, material.' The administrative text types contain six terms below the subcategory heading Clothing (including pannus); terms at this level of the semantic hierarchy have the widest range of meaning: two of the terms for clothing in general also have more particular senses (veste and vestement, which also refer to ecclesiastical vestments); one term also has a range of quite general senses (harnesse, which in early use signified clothing, attire, and bedding, as well as, more generally, accessories or trappings). The romance vocabulary contains three terms below the subcategory headword Clothing: gere, robe, and tire. The word robe simply means 'clothing.' One of the other terms has a wide range of meaning comparable to that found in the administrative texts: gere (clothes; harness; bedclothes). The other lexical item has further senses, but they are more narrowly focused than the 'clothing' sense: tire also signifies 'an outfit; a woman's fine headdress; an ornament of woman's dress.' The administrative text types contain two words below the subcategory headword Accessories: harnesse, for which one of the senses is 'accessories' and ornament, which has the sense 'adornment(s); accessories', and in some instances may refer to fabrics, hangings, or ornaments of precious metal, and so is a general term with quite a wide range of meanings. Unlike the administrative text types, the romances do not contain any terms that signify accessories in general. The administrative text types contain two terms below the subcategory headword Decoration (in cloth and clothing contexts) (esclaires and troefles). The romances have one term for the subcategory headword Decoration, gaudi. The administrative text types contain one term for the subcategory heading Fur (furre; there are also many terms for the fur of particular animals, and for fur derived from particular parts of an animal). The romances do 
not have a word signifying 'fur', but they do include a term at this level of the semantic hierarchy: the term fellez has the senses 'skin of animals stripped from the bodies and left with or without the hair attached; skins, hides, pelts, or fleeces; also, such skin, or a piece of such skin, treated and used for clothing.' The romances thus have fewer vocabulary items with general meanings (seven in the romances, 13 in the administrative documents), and they are spread over slightly fewer categories (five, in the romances, six in the administrative documents), because the romances do not have separate general terms for accessories and decorative devices. The numbers of individual lexical items in each subcategory are not important here, as we are looking at the vocabulary of one text type set against several grouped together under the rubric of administrative documents. The discrepancies do suggest that it is possible that the romances contain more of their vocabulary at the more fine-grained levels of the semantic hierarchy. To confirm this, we need to look more closely at the distribution of the vocabulary of both sets of text types in their semantic classifications (note that some terms appear more than once because they are polysemous). ${ }^{30}$

General terms in at least one administrative text General terms in the romances but not the type but not the romances administrative text types

Cloth

Cloth

pannus

$\underline{\text { bofu }}$

Clothing

Clothing

apparaile; clathes; harnesse; veste;

gere; robe; tire

vestement

Bedding

Bedding

harnesse; lytere.

gere 
Furnishings

apparaile furnishings

Accessories

esclaires; harnesse; ornament

Decoration

Decoration

$\underline{\text { esclaires; }}$ troefles

gaudi

Fur

Animal hide

furre

fellez

Table 1

\section{III.II SUBCATEGORIES AND SUB-GROUPS OF VOCABULARY}

Further information is provided by examination of the number of sub-groups below the subcategory headings that make up the DRESS AND TEXTILES semantic field the vocabulary of the two sets of text types contains, and whether the groupings extend below the level of subgroups. A greater number of sub-groups suggests a greater specificity of expression and the use of a wider range of technical terms. More vocabulary at this level suggests a preponderance of technical vocabulary in the genre. We have seen the number of general terms in both text types, but there are also some subcategories of vocabulary where there is no superordinate term, so a text type may have more sub-groups of vocabulary than is indicated by the number of general terms at the top of the semantic hierarchy, though the general terms show the main subcategories into which the vocabulary falls.

As shown above, in the Cloth subcategory, only one term signifying cloth in general is found in each of the two sets of text types. Below that, the subcategory Cloth breaks down into four sub-groups in the administrative texts: 
.Textiles

alyr; $\underline{\text { blanket; }}$ bustian; $\underline{\text { camelino }}$; $\underline{\text { CandelWekstrete; }}$ canvas; carde; chamelet; cloth of gold; cloth of siluer; d'aignel; drap de soye; drape d'or; damask; frees; fustian;

Gildeford; kerseys; laine; lambe; lawn; lienge tele; linure; lure; musterdevylers; ray;

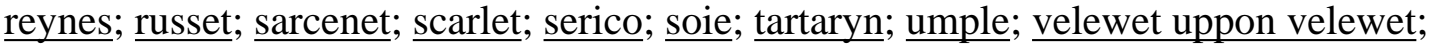
white; wolle; worsted

..Cloth of a particular color or pattern

blueto; colour; crosse werk; medley; persico; velwetmotley

..Textiles used for specific purposes

$\underline{\text { cadas; }} \underline{\text { coton; }} \underline{\text { nettes }}$

\section{..Component of textile}

gold; lineis

The first sub-group, Textiles, mostly comprises names of fabrics, though not perhaps in the way we understand them today, for example, bustian (type of cloth, probably of cotton and of foreign manufacture; frequently described as white); the second is Cloth of a particular color or pattern, for example, blueto (blue woolen cloth); the third is Textiles used for specific purposes, for example, cadas (material used for padding or stuffing, such as silk or cotton wool); and the final sub-group is Component of textile, for example, lineis (thread). The same subcategory of the romance vocabulary has five sub-groups:

.Large piece of cloth

$\underline{\text { chief }}$ 
.Textiles

$\underline{\text { alexandrine; }}$ bleaunt; $\underline{\text { bliauz; }}$ bys; chesil; Cyprus; $\underline{\text { Indesandel; pal; tars; tolouse }}$

..Cloth of a particular color

vyolet

..Textiles used for specific purposes

$\underline{\text { sacca cilicino }}$

..Component of textile

$\underline{\text { fildore }}$

The first sub-group, Large piece of cloth, has only one term, chief (bolt, large piece of cloth); the second, Textiles, is similarly made up mostly of cloth names; for example, Indesandel (a thin, rich, silken material); the third, Cloth of a particular color, has only one term, vyolet (cloth of violet colour); the fourth sub-group, Textiles used for a specific purpose, has one term, sacca cilicino (sackcloth, a term often used to describe penitential garments or bedding); the final sub-group is Component of Textile, here the term is fildore (gold thread). The number of subcategories in the romance text type compared with the number in the administrative text types suggests a greater use of specific vocabulary in the romances, particularly in light of the fact that we are looking at the vocabulary of one text type set against the lexis of a variety of text types (though all administrative). In terms of the semantic hierarchies, the sub-groups below the subcategory heading Cloth go to two levels below the headword in the vocabulary of both sets of text types. 
The subcategory Clothing breaks down into five sub-groups in the administrative texts:

.Clothing for specific purposes

liuerey; veste; vestement

\title{
.Garments
}

$\underline{\text { boteaux}}$; camisiam; capa; capucia; chaperon; chauceure; cloke; collobium; cordon'; courtby; doublet; hewk; hures; jaket; perpoint; solers; $\underline{\text { supertunicale; toga; tunicam }}$

\author{
..Headgear

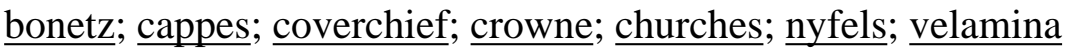

..Garments for specific purpose

$\underline{\text { aketouns}}$; albas; $\underline{\text { cappes of astate; }}$ casula $; \underline{\text { cope }}$; Cordewaneres leueray; dalmaticas;

doublat of fence; manipula; riding gowne; stola; weddynggown

..Part of a garment

$\underline{\text { colers; }}$ crounes of cappes for children; crimiles; ffurrereur; fret; furring(is); laqueos;

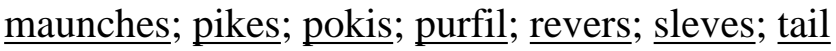

The first sub-group, Clothing for specific purposes, consists of livery for example, liuerey (official recognizance, garment or uniform) and ecclesiastical garments (for example, veste and vestement, with the sense 'ecclesiastical vestments'); the second, Garments, contains terms for specific garments such as hewk (long lined outer garment); the third, Headgear, has terms signifying specific types of hat and hood, for example bonetz (usually a man's head- 
covering without a brim); the third, Garments for specific purposes, contains specific livery, some ecclesiastical garments, and some terms in which the purpose forms part of the term itself, for example compound terms such as weddynggown (wedding dress); the final subgroup here is Part of a garment, for example, crounes of cappes for children (peaks of children's caps).

The same subcategory, Clothing, in the vocabulary of the romances also has five subgroups:

.Garments

bleaunt; bliauz; brech; capados; chainsil; chemise; gorger; gyde; jepun; kelle; scherte

..Headgear

$\underline{\text { cercle; }} \underline{\text { coronal; }}$ crounne; tressour; tire; wympill

..Garment for specific purpose

$\underline{\text { cote-armure }}$

..Fastenings for garments

$\underline{\text { botenus; gerdylstede; loupe; pwonges }}$

..Part of a garment

borde; frenges; hemmez; lappes; pane; $\underline{\text { skyrtez }}$

There is some overlap with the sub-groups of the vocabulary of the administrative text types, but they are not identical. The sub-groups of the vocabulary of the romances are: Garments, this sub-group also comprises names of specific garments, though they do not always readily 
translate onto modern items for clothing, for example, gorger (article of female dress covering the neck and bosom); capados (garment covering the neck and shoulders, a cape). The Green Knight's capados is thought by Nevinson to have been a hood with shoulderpieces) $;{ }^{31}$ the second sub-group, Headgear consists almost entirely of ornamental headdresses, which are worn by women; for example, coronal (a precious circlet, often of gold and gems, worn about the head for ornament or to show rank) and tressour (net, arrangement of ties, bands, ribbons etc. for the hair); the third sub-group, Garments for specific purposes, contains only one term, cote-armure (garment embroidered or painted with heraldic arms and often worn over armour); the sub-group Fastenings for garments is not found in the vocabulary of the administrative text types. It contains terms such as botenus (buttons). Here we may note that the lexicalization of specific concepts indicates the interest that particular language users have in the subject. Fastenings are mentioned in at least one place in the administrative documents (see the sumptuary law quoted below, which mentions garments being 'butonede or hole be fore'); the object used to accomplish the 'closed' effect of the garment is not named. The final sub-group, Part of a Garment contains, for example, the term lappes (parts of a garment loose enough to admit of being raised, folded or seized; the lower part of a shirt, skirt, etc.). There are two terms for shoes in the administrative documents, and three that seem unambiguously to be under-garments in the romances, but it seemed as if it would be unnecessarily arbitrary to extract these terms to make further subgroups below the subcategory heading Garment. The sub-groups in the vocabulary of both the administrative text types and the romances extend to two places below the subheading.

We know that medieval homes (including castles) were filled with fabrics in the form of cushions, seat covers and hangings. ${ }^{32}$ The administrative texts have one very general term, aparaile, which has the sense 'furnishings' in addition to its 'apparel, clothing' sense. Both sets of text types have superordinate terms signifying 'bedding' (see Table 1), with sub- 
groups containing terms for specific items of bedding below it. The vocabulary of the administrative text types has one sub-group here:

.Parts of a bed/ bedclothes

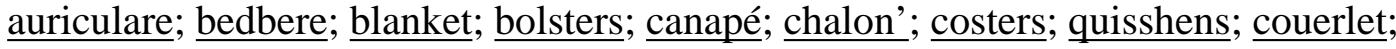
$\underline{\text { couertour; curteyns; featherbed; heuedshite; linchiamentis; lynne bed; materas; }}$ $\underline{\text { naperie; }}$ oraillers; trussyngbedes; wytele

This subgrouping contains a number of items which are terms for bedcovers, for example, bedbere, chalon', couerlet, and couertour, as well as other items of bedding such as oraillers (pillows) and materas (mattress).

The romances have two subgroupings of vocabulary below the subcategory heading Bedding:

\author{
.Parts of a bed/ bedclothes \\ $\underline{\text { bolstrum; coddys; queldepoyntes; rydalus }}$
}

..Curtains' accessories

$\underline{\text { cordes; }} \underline{\text { ropez }}$

The sub-group Parts of a bed/ bedclothes contains terms such as coddys (pillows, cushions), quyltus (covers stuffed with wool, down, hair, etc., used as a mattress, cushion, or coverlet for a bed), and rydalus (curtains for a bed; we find a different term, curteyns, with the same sense, in the administrative text types); The second sub-group, Curtains' accessories, contains two lexical items, cordes and ropez, both of which are terms for the cords on which the 
curtains are hung. The vocabulary of the romances has more sub-groups below this subcategory heading, and it has a sub-group that extends to two places below the subcategory heading here, while the sub-group of the vocabulary of the administrative text types extends to only one place below the subcategory heading. These two results indicate the use of more specific, technical vocabulary in this area in the romances.

Both sets of text types also have terms signifying specific soft furnishings also. There are four sub-groups in this subcategory in the vocabulary of the administrative text types:

.Other household linen

bordcloth; naperie; wasshyngtowels

.Decorative hangings

$\underline{\text { bankers; }}$ docere; fete; frontel; hallyng

..Part of a decorative cloth

fete

Seat covers

$\underline{\text { bankers }}$

The first sub-group, Other household linen, contains specific examples such as bordcloth (tablecloth); the second, Decorative hangings contains terms for wall-hangings, for example, hallyng, hallyng' (wall hangings, room hangings or tapestries) and also terms such as docere (curtain, hanging, a decorative textile hung behind a bed, seat or altar). The sub-group Part of a decorative cloth has one lexical item, fete, a term that has the sense 'hanging' and also 'the lower ends or sides of a strip of cloth'; and the sub-group Seat covers has the sole lexical item 
$\underline{\text { bankers }}$ (bench or chair cover(s), a covering(s) of tapestry or similar, as covering for furniture), a term which appears in Anglo-French and Latin as well as Middle English. ${ }^{33}$

The vocabulary of the romances has one sub-group of vocabulary in this subcategory that encompasses soft furnishings, but has no superordinate term:

.Other household linen

towellus of Eylyssham

The sole term, towellus of Eylyssham (towels from Aylsham) derives from the fact that Aylsham in Norfolk was famous for its linen in the late-medieval period, and offers more evidence of the upscale nature of the majority of the DRESS AND TEXTILE-related terms in the romances.

The administrative text types have two terms meaning accessories in general, while the romances have no vocabulary at that level for this subcategory. The vocabulary of the both the administrative text types contains one sub-group comprising individual accessories:

\section{.Accessories}

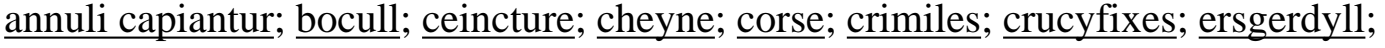

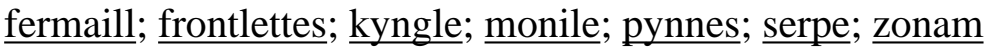

The terminology in this subgroup includes terms for belts or sashes, such as ceincture, corse and zonam, and ambiguous terms signifying jewellery, for example kyngle (girdle or brooch) and monile (brooch; necklace).

The romances do not contain any general terms signifying 'accessory', but there is one sub-group of vocabulary containing terms for specific accessories:

.Accessories

bauderyk; gerdylstede; nevyn; pensel 
This sub-group also contains terms for belts, for example gerdylstede (a belt worn around the waist or hips, used for fastening clothes or for carrying a sword, purse, etc.) It also contains the slightly ambiguous term nevyn which seems to signify some sort of ornament or clasp..$^{34}$ The earliest recorded romance/poetic occurrence of this term is in Sir Degrevant. ${ }^{35}$

Both sets of text types also have general terms for decoration; Table 1 shows that these are lexical items with wide meanings that include the idea of ornaments, often showy ones. The lexis of the administrative text types has one sub-group, containing just one lexical item:

\section{.Decorations}

$\underline{\text { stodys }}$

The romances also have only one sub-group under the category headword Decorations:

.Decorations

$\underline{\text { barres; }}$ besauntus; $\underline{\text { knotez; }}$ naylez; $\underline{\text { semez }}$

This subgroup also includes terms signifying studs or decorative metal ornaments, knotez and

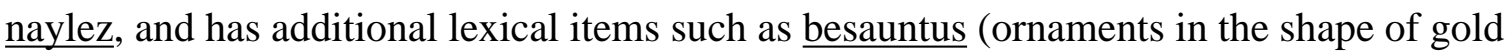
coins).

There is a term signifying Fur in the administrative texts (ure); the romance texts do not contain this subcategory but there is an equivalent superordinate term in the romance vocabulary (the term fellez, which signifies animal skins stripped from the bodies and left with or without the hair attached; skins, hides, pelts, or fleeces; also, such skin, or a piece of such skin, treated and used for clothing). The vocabulary of the administrative text types has two sub-groups:

.Furs 
byce; beuer; bugee; calabre; chat; conyng; cristigray; cuniculis; ficheux; foynes; gupille; grey; gret menyvere; ionetis; letuse; $\underline{\text { martrens; }}$ menyver; oter; sables; wylde $\underline{\text { catis }}$

..Fur from specific part of an animal polles; protes

The first sub-group, Furs, comprises terms for the fur of individual animals such as beuer (beaver), calabre (squirrel), and conyng (rabbit); the second, Fur from a specific part of the animal, contains two terms, poles (fur taken from the heads of the animal) and protes (fur taken from the throats of the animal).

The vocabulary of the romances has only one sub-group:

.Furs

blaunner

This sub-group contains only one term, blaunner (kind of fur, possibly ermine); other terms for furs appear in the romances: variants of the term ermyn (ermine) appear in five of the romances, but the term also occurs in the sumptuary laws. In this case, the sub-group of the romance vocabulary extends to only one place below the subcategory heading, while the administrative text types have a sub-group which extends one place lower (the terms specifying the part of the animal from which the fur comes), suggesting greater specificity of terminology in this semantic area in the administrative text types.

The last subcategory in both sets of text types is Armor. Neither of the text type groupings has any general terms meaning armor. The vocabulary of the administrative text types has one sub-group: 
.Armor (for specific body parts/ specific garments)

brest plat; esperons ; gauntz de plate; gorgeat; ketil hatte; legge harneys; legsplentis; pesane; rerebrace; vambrace; ventaile; yrn hat

This subgroup includes, for example, esperons (spurs) and gorgeat (mail collar or armor for the throat; metal protection for the chin and neck). Some of the terms are compounds specifying the body part to be protected, for example brest plat (armor protection for the chest and torso) and legge harneys (metal armour for the leg).

The romance text type has two sub-groups of vocabulary below for the Armor subcategory:

.Armor for specific body parts/ specific garments

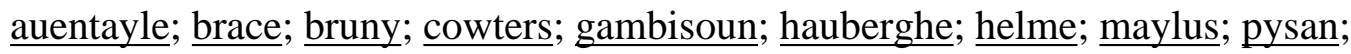
plate; polaynez; quyssewes; $\underline{\text { sabatounz; }} \underline{\text { sporez }}$

..Fastenings for armor

lachet; $\underline{\text { vrysoun }}$

The sub-group Armor for specific body parts/ specific garments includes terms such as brace (pieces of armour covering the arm) and cowters (pieces of armor to protect the elbow); the second sub-group, Fastenings for armor, contains two terms, lachet (loop of cord, leather, etc., used as a fastening for armor) and vrysoun (a band of embroidered silk which attached the auentayle or camail). The sub-group Fastenings for armor extends to two places below the subcategory headword, while the only sub-group below the category heading Armor in the administrative text types extends to only one place below the headword. This suggests a use of more specialized vocabulary in this semantic area in the romance text type. 
IV. THE ROLE OF TECHNICAL TERMINOLOGY IN CONSTRUCTING THE ROMANCE TEXT TYPE

We can consider the literary effect of these vocabulary choices by examining an example from a Middle English romance in detail and comparing cloth and clothing terms found in this romance with some of their distribution in various of the administrative documents. Here is the moment in Sir Launfal when the eponymous hero has given away all his money and cannot even go to church because of his lack of clothing. He has been refused or declined all invitations to dine and instead rides out to the forest. The day is hot, so he folds his cloak and lies down for a rest, and as he is lying there, he sees two maidens come out of the forest:

As he sat yn sorow and sore

He sawe come out of holtes hore

Gentyll maydenes two:

Har kerteles wer of Indesandel,

Ylased smalle, jolif, and well —

Ther myght noon gayer go.

Har manteles wer of grene felvet,

Ybordured wyth gold, ryght well ysette,

Ypelured wyth grys and gro.

Har heddys wer dyght well wythalle:

Everych hadde oon a jolyf coronall

Wyth syxty gemmys and mo. (229-240) $)^{36}$ 
In this extract the women wear kerteles. This term has a very wide range of definitions across the medieval period, including 'general term for an upper-body garment of various descriptions: a man or boy's tunic, (later) a woman's gown; originally short but with varying lengths; on occasion described as made of wool or fur.' ${ }^{37}$ In the will of Isabel Gregory dated 1431-2, we find the following reference to a kirtle: 'also I be-quethe to Ione my dowter, a blew goune and a grene kyrtyll, and a schete. ${ }^{38}$ Other legacies of cloth and clothing in this will include a table-cloth, bed, mattress, sheets, cushions, cloaks, and gowns. In Margaret Asshcombe's will, dated 1434, the term appears as follows:

also y be-quethe to Clemens, the woman that kepes me, a gowne of Musterdevylers, $\&$ a kyrtell of musterdevylers with grene sleues, $\&$ an hode of blak of lure, $\&$ an hod of blewe. [...] alsoo y bequethe to Aneys Copursmyth a combe of yverie, \& to Aneys hir' mayden', a russet kyrtell furred with lambe. ${ }^{39}$

In this context, the kirtle bequests look quite downscale, one is left to the housekeeper and one to a maid; the latter kirtle is made of russet, an inexpensive woollen cloth, and is only trimmed with lambswool. ${ }^{40}$ The context of the term's appearance in the sumptuary legislation is the set of injunctions on the dress and ornamentation of female religious imposed by the Bishop of Lincoln in 1441 in response to accusations made against the (evidently) opulently dressed prioress. In an earlier examination she had confessed to wearing all except for cloth of Rennes, though she claimed that she only wore a fur cap 'of estate' (status) on medical grounds. In the injunction the term appears thus:

Also we enioyne yowe [...] that none of yow, the prioresse ne none of the couente, were no vayles of sylke ne no syluere pynnes ne no gyrdles herneysed wyth syluere or 
golde, ne no mo rynges on your fyngres then onne, ye that be professed by a bysshope, ne that none of yow use no lased kyrtels, but butonede or hole be fore, ne that ye use no lases a bowte your nekkes wyth crucyfixes or rynges hangyng by thayme. ${ }^{41}$

The context here suggests that kirtle is a more elevated item than is indicated in the wills: the other (forbidden) items include silk veils, silver pins, and rings and other items mentioned are accompanied by rich descriptors such as the 'gyrdles herneysed wyth syluere or golde.' This is also true of the kirtles, which must not be laced but buttoned or not require any fastening. In the petitions, we find a reference to the term kirtle in a list of clothing, jewellery, accessories, and money. A petition for the king's pardon made on behalf of Agnes Balle who was being held in prison in London accused of stealing various items includes a 'kertill de russet pric' de xij d.' (kirtle of russet worth 12d). ${ }^{42}$ Agnes Balle's royal pardon, also issued in 1403, refers to it as 'unum kyrtyll de russeto precii duodecim denariorum' (a kirtle of russet worth twelve pence).$^{43}$ In Sir Landevale, the direct source for Sir Launfal, the women also wear kirtles ('Kyrtyls they had of purpyl sendell, / Small i-lasid, syttyng welle.' ${ }^{44}$ Here 'kyrtyls' translates the term bliauz. During the twelfth century the term bliaut signifies an elaborate dress and a costly fabric in texts from England and France, and it continues to carry these senses in Britain into the fifteenth century. These usages suggest that kirtle has a wide range of senses, but is used quite precisely in the romances to translate a term that is more upscale than the garment designated in the wills, but which may have connotations of wealth as shown in the sumptuary laws. The petition on behalf of Agnes Balle is in Anglo-Norman, as is the ultimate source of Sir Launfal, and it may be that the idea of richness associated with the term has been carried over from Anglo-Norman into these particular Middle English texts. 
The women's dresses are made of Indesandel, a term only found in this romance within the text base. It is a thin silken material or indigo silk. It appears to be a compound term made up of the element indigo and sendal, a fine costly fabric (silk or lawn, cotton or linen), usually light, but available in heavier weights. This term is found in various forms in the wills and romances. The Latin will of Martin of St Cross, chaplain of the Bishop of Durham, dated 1259 includes the bequest:

tertiam capam de serico ecclesie beate Marie Karl', capelle sancti Edmundi de Gatesheved tunicam et dalmaticam de cendallo viridi; et auriculare de serico ad textum subportandum. ${ }^{45}$

(The tunic and dalmatic of green sendal to the chapel of St Edmund in Gateshead and the silk pillow on which the text was carried.)

Here, the reference is surrounded by other examples of rich textiles: there is mention of a cope and a chasuble both of samite and a cope and entire vestment of Spanish cloth-of-gold. As is typical for the wills, the clothes are precisely described as to decoration: one of the vestments is represented as being bruddato integro (fully embroidered). Similarly, the textiles of which each garment is made are identified by color: as well as the green sandal of the tunic and dalmatic, the cope and chasuble are described as being of red samite, and there is a frontal of striped silk, and a black towel. The identification of specific garments in wills by their color goes back to the earliest examples in Old English. ${ }^{46}$ We may note, too, the specification of color in the mention of sendal in a later will, that of Lady Alice West, dated 1395 in which she leaves her son Thomas, among other things: 
my beste fetherbed, and a blu caneuas, and a materas, and twey blankettys, and a peyre schetes of Reynes, with the heued shete of the same, and sex of my best pilwes, wich that he wol chese, and a bleu couertour of menyuer, and a keuerlet of red sendel ypouthered with Cheuerons ${ }^{47}$

It seems possible that the romance writers were imitating this precision in their description of dress. The pattern is echoed in our quotation from Sir Launfal in the depiction of the women's mantles, which are 'of grene felvet, / Ybordured wyth gold.' The term sendal also

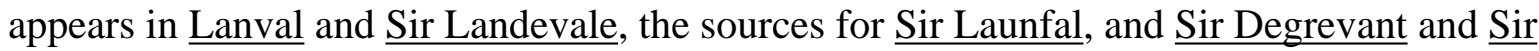
Gawain and the Green Knight. These last two romances are noted for their use of precise and detailed vocabulary (particularly in the field of dress and textiles), and the term sendal appears in the description of Melidor's bed quoted above: in the list of bedding, her pillows are described as being 'of sendal.' In Sir Gawain and the Green Knight, the term appears once, in lines which are not easy to translate:

Whene Guenore, ful gay, grayped in pe myddes,

Dressed on pe dere des, dubbed al aboute,

Smal sendal bisides, a selure hir ouer

Of tryed tolouse, and tars tapites innoghe ${ }^{48}$

Guinevere is sitting on a splendid platform decorated all round with fine silken cloth at her sides. This definition of 'smal' does not appear in the Middle English Dictionary, but it seems sensible and is the gloss given in the edition of the poem edited by Tolkien, Gordon and Davis. $^{49}$ 
The women wear manteles. This is a widely used term in the medieval period. The Lexis Project database defines it as an:

article of cloth or similar wrapped about the person, a cloak, cape, wrap or other outer covering; through the medieval period, came to be used for an outer garment of various descriptions, usually a sleeveless cloak worn over the tunic or similar. In certain instances referring specifically to such items as worn by nobility, royalty or ecclesiastics

and the term exists in Latin, Old and Middle English, Anglo-French, Old Scots, Irish and Welsh. It occurs in three wills in the text base. In the Latin will of Peter of Aigueblanche, bishop of Hereford, dated 1268, the testator leaves his chaplain, 'robam nostram meliorem, scilicet tunicum et supertunicale de bloyeto sive de persico et mantellum eiusdem' (our best outfit, namely a tunic and surcoat of light blue cloth or of dark blue cloth and a matching cloak). ${ }^{50}$ In the Latin will of Thomas Harpham, the testator leaves 'domino Waltero de Harpham mantellum meum de Winchelsee' (Lord Walter of Harpham my cloak from Winchlesea). ${ }^{51}$ The mantels in question are given descriptors (e.g. of Winchlesea) presumably because they are not unusual items and the executors will need some way of identifying them. The mantel mentioned in the will of Roger Flore (or Flower) Esq. is slightly different. The testator ends by bequeathing his manorial estates of Sternby and Braceby in Lincolnshire, with their rights, to his wife:

all pe while she lyvep sool withoute husbond. And if she take pe mantel and pe rynge, and avowe chastite, than wul I pat forth-whith my said ioint feffes make her astate, for 
terme of hir' lif, of pe same too lordshipes, vp condicion pat she lyve sool, withoute husbond ${ }^{52}$

The mantel here forms part of an ecclesiastical outfit signifying the vow to live chastely. In the Act of October 1363, we find mantels mentioned in a list of garments. Knights who have land or rent within the value of 200 marks may not wear cloth that costs more than 6 marks, they may not wear cloth-of-gold or have certain items lined or trimmed with fur:

Et q'ils ne usent drape d'or, ne cloche, mantel ne goune fururez de menevoir purez, manches d'ermyns, ne nul apparaill broidez de perre n'autrement ${ }^{53}$ (And they may not wear cloth-of-gold, or a cloak, mantle or gown lined with pured miniver, sleeves of ermine or any apparel embroidered with precious stones or otherwise)

Again, it is not the mantel itself which denotes wealth above the stations of those who wish to wear it - it all depends on what it is made of, or trimmed with. We may note that the women in Sir Launfal wear mantels made of made of green velvet bordered with gold beautifully adorned, and edged with grey and white fur. Mantels are also found in Sir Landevale, in the Anglo-Norman Lai le Fresne and its Middle English version, the Lay le Freine. The term has a slightly different valence in the two versions of the Freine story. In Marie de France's Anglo-Norman version, Freisne goes to prepare the room for her sister's marriage (to the man she herself loves), 'De sun mauntel est desfublee' (she takes off her cloak) and summons the chamberlains and shows them how she wants the bed made. Dissatisfied with their arrangements, she takes out 'sun palie' (the brocade) in which she was wrapped when her mother left her in a tree and places it over the 'covertur' (coverlet) that had been put on the 
bed. In the Middle English version, the term mantel seems to be used to signify a general covering. Freine does not stop to take off any garments when she reaches the bridal bedchamber, but quickly goes to her chest and takes out her costly baldachin - 'Fayrer mantel [covering] nas ther not' - and lays it on the bed. The same term is used to denote the baldachin itself when her mother catches sight of it, triggering the recognition scene: 'But whan the levedi that mantyll seighe / Sche wel neighe swoned oway.' There are three mantels in Sir Gawain and the Green Knight, the first worn by the Green Knight on his entrance to Arthur's court at Camelot, the second given to Gawain on his arrival at Lord Bertilak's castle, and the third worn by Lady Bertilak when she comes to seduce Gawain on the third day. All three are fine rich garments but we only know this because each is lined and trimmed with fur. Gawain's is additionally made of a rich brown fabric and in the case of both his garment and that of the Green Knight, the fur is specified as ermine.

It should also be noted that many of the wills discussed here include very detailed bequests of beds and bedding, adding weight to the idea that these were important household objects but also underlining the similarities between the romances and the administrative text types.

\section{CONCLUSION}

This study examines vocabulary relating to the semantic field DRESS AND TEXTILES in a selection of medieval insular romances from the twelfth to the fifteenth centuries. The lexical items were classified into semantic hierarchies and the resulting classification of the romance vocabulary from this semantic field was compared with a classification of terms from the same semantic field found in a selection of administrative text types, namely wills, sumptuary laws and petitions, from the same period. This was in order to discover how far my impression that the literary genre makes use of an unexpected amount of precise technical terminology is borne out. The present study shows that in particular sub-categories of the 
vocabulary relating to DRESS AND TEXTILES writers of medieval romance offer more focused depictions that require the use of particularly detailed lexis. In the Cloth subcategory, while the semantic hierarchies for the vocabulary of the administrative text types and the romance text type extend to the same number of places below the headword, the vocabulary of the romances breaks down into a greater number of sub-groups. The semantic classification of the vocabulary representing soft furnishings in the romances falls into a lower number of subgroups than that of the administrative text types, but the romance text type contains a subgroup that goes to one place further down the semantic hierarchy than is found in the classification of the vocabulary of the administrative text types. The semantic classification of the vocabulary in the romances for armor falls into one more sub-group than that of the administrative text types, and that extra sub-group contains vocabulary at one place further down the semantic hierarchy that the vocabulary relating to armor in the administrative text types. Focusing on the technical terminology deployed by the writers of the medieval romances offers a new way to engage with the question of the audience for whom these texts were designed. This is a vexed question. As we have seen, the writing of the romances has generally been denigrated. Opinions about their audiences differ on the basis of the interpretation of the worldview they contain. Editing Sir Amadace, Edward Foster comments on its celebration of power and money seen from lower end of the social scale, concluding that the romance is 'popular not aristocratic. ${ }^{54}$ Most influential, perhaps, has been the view of Per Nykrog, which was formulated to account for the audience for the fabliaux. In a widely-accepted interpretation of the fabliaux as courtly burlesques, Nykrog proposes that the fabliaux belong primarily to an aristocratic milieu, and argues that they do not make sense unless they are read as comments on courtly customs or on the effects of courtly literature. I suggest that the vocabulary choices I have highlighted here show that the romances traded on the recognizability of the world they depict. The terminology deployed for the textiles and 
garments mirrors that found in the administrative documents to a degree that would not seem necessary when we consider that this is primarily a fantasy genre with elements of the supernatural found in curtain ropes made of mermaids' hair (Sir Degrevant) and magical sashes that protect the wearer even when he presents his neck for beheading (Sir Gawain and the Green Knight). Against this aspect of the genre are placed the fine details of the everyday life of its aristocratic audience, such as the fur-linings of their mantles and fine silken textiles of their kirtles. Almost without exception, the definitions of the terms below the subcategory heading Textiles in the romance text type contain modifiers such as 'fine', 'costly', 'precious', etc., for example, bys (a precious kind of linen or cotton cloth); chesil (fine linen); cyprus (costly fabric). The names of these fabrics would be known to an aristocratic audience from the accounts of their wardrobe-keepers and the sumptuary laws issued by the king and Parliament, and it was vocabulary they themselves could conjure when describing their own garments in bequests to spouses and children. Despite the assessments of the writing by Pearsall, McDonald and others, this study shows that the writers of medieval romances were in many cases much more sophisticated in their awareness of audience in their construction of this literary text type than has been generally allowed hitherto.

\footnotetext{
${ }^{1}$ A distinction has been drawn between the terms text type and genre by Douglas Biber, who suggests that genre distinctions are based on external criteria while text type distinctions are made on the basis of similarities in internal linguistic forms of texts. In practice, the two
} 
terms are frequently used interchangeably by linguists (see Douglas Biber, $\underline{\text { Variation across }}$ Speech and Writing (Cambridge: Cambridge Univ. Press, 1988), pp. 70, 170; David Y. W. Lee, "Genres, Registers, Text Types, Domains, and Styles: Clarifying the Concepts and Navigating a Path through the BNC Jungle," Language Learning and Technology, 5 (2001), $38,41)$.

${ }^{2}$ Louise Sylvester, "Middle English Style," in The Bloomsbury Companion to Stylistics, ed. Violeta Sotirova (London: Bloomsbury Academic, 2015), pp. 583-606.

${ }^{3}$ See Walter J. Ong, “The Green Knight's Harts and Bucks,” Modern Language Notes, 65 (1950), 536-539 and Joseph Kropp, “On the Translation of Middle English hastlette3,” Notes and Queries, 237 (1992), 438-441.

${ }^{4}$ Louise Sylvester, Mark Chambers and Gale Owen-Crocker, ed. Medieval Dress and Textiles in Britain: A Multilingual Sourcebook, Medieval and Renaissance Clothing and Texiles 1, (Woodbridge: Boydell, 2014), p. 338.

${ }^{5}$ See Nicola McDonald, “A Polemical Introduction," in Pulp Fictions of Medieval England: Essays in Popular Romance, ed. Nicola McDonald (Manchester: Manchester Univ. Press, 2004), p. 2; see also Jane Gilbert, “A Theoretical Introduction,” in The Spirit of Medieval English Popular Romance, ed. Ad Putter and Jane Gilbert (Harlow: Pearson Education, 2000), pp. 15-31, notes pp. 34-38.

${ }^{6}$ Derek Pearsall, "Middle English Romance and its Audiences," in Historical and Editorial

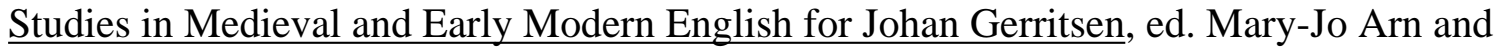
Hanneke Wirtjes, with Hans Jansen (Groningen: Wolters-Noordhoff, 1985), p. 41; see also Dana M. Symons, "Does Tristan Think, or Doesn't He? The Pleasures of the Middle English Sir Tristrem," Arthuriana, 11 (2001), 5.

${ }^{7}$ McDonald, "Polemical Introduction,” p. 14. 
${ }^{8}$ Heiner Gillmeister, “Chaucer's 'kan ke dort' (Troilus II.1752) and the 'Sleeping Dogs' of the Trouvères," English Studies, 59 (1978), 310-323. See, Louise Sylvester and Jane Roberts, Middle English Word Studies: A Word and Author Index (Cambridge: D. S. Brewer, 2000). ${ }^{9}$ W. A. Davenport, "Sir Degrevant and Composite Romance," in Medieval Insular Romance:

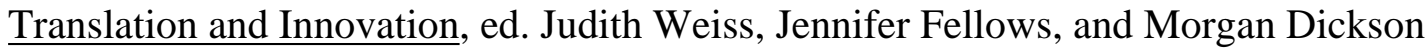
(Cambridge: D. S. Brewer, 2000), p. 117. This study appeared too late to be cited in Sylvester and Roberts, Middle English Word Studies.

${ }^{10}$ Manfred Görlach, Text Types in English (Berlin: Mouton de Gruyter, 2004), p. 105.

${ }^{11}$ For the term ‘domain-specific English', see Marina Dossena and Irma Taavitsainen, "From Synchrony to Diachrony in Domain-specific English: An Introduction,” in Diachronic Perspectives on Domain-Specific English, ed. Marina Dossena and Irma Taavitsainen, Linguistic Insights, 40 (Bern: Peter Lang, 2006), pp. 7-17. For 'discourse-specific vocabulary', see Joanna Bugaj, “Sources of Discourse-specific Vocabulary in Middle Scots Administrative Records: An Etymological Study of Binominals," in Dossena and Taavitsainen, ed. Diachronic Perspectives, pp. 109-132. The descriptions 'technical language' and 'language for special purposes' are used by, for example, Waldemar Lib, “Technical Language as an Indicator of Technical Culture," Informatol, 43 (2010), 54-57 and Juan C. Sager, David Dungworth and Peter F. McDonald, English Special Languages: Principles and Practice in Science and Technology (Wiesbaden: Brandstetter, 1980).

12 Bugaj, "Sources of Discourse-specific Vocabulary," p. 110.

${ }^{13}$ Mary B. Speer, “Reading Romances: Genre as Process,” Degré, 11 (1987), 71.

${ }^{14}$ Caroline Jewers, Chivalric Fiction and the History of the Novel (Gainesville: Univ. Press of Florida, 2000), p. 10. 
${ }^{15}$ Susan Crane, Insular Romance (Berkely: Univ. of California Press, 1986), p. 10; Douglas Kelly, The Art of Medieval French Romance (Madison: Univ. of Wisconsin Press, 1992), p. 318.

${ }^{16}$ Crane, Insular Romance, p. 10.

${ }^{17}$ Kelly, The Art of Medieval French Romance, p. 11.

18 The detailed description of the cloth occurs at 11. 86-180 of Emare in The Middle English

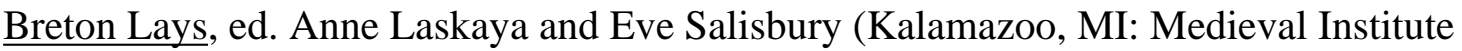
Publications, 1995); the scene in which Freine's mother recognizes her daughter through the cloth she has spread on her sister's marriage bed is at 11. 369-388 of Lai le Freine in Laskaya and Salisbury, ed. The Middle English Breton Lays; the quotation from Malory comes from Malory: Works, ed. Eugène Vinaver (Oxford: Oxford Univ. Press, 1971), 623/30-32; XVIII, 9.

19 The project Medieval Dress and Textile Vocabulary in Unpublished Sources was based at the University of Westminster and the University of Manchester. I am grateful to the Leverhulme Trust for funding the research for this project of which I was principal investigator and Gale Owen-Crocker co-investigator. The volume is Sylvester, Chambers, and Owen-Crocker, ed. Medieval Dress and Textiles in Britain.

${ }^{20}$ Such items do appear in the wills, but they are only part of the set of items in the semantic field DRESS AND TEXTILES that appear as bequests.

${ }^{21}$ It should be noted, though, that the lists exclude terms shared by one of the selected text types and another in the text base that is outside the selection, e.g. cadac', cadas (material used for padding or stuffing; either silk or cotton wool), which appears in the extracts from the sumptuary laws and also in the accounts.

${ }^{22}$ Louise Sylvester, “Technical Vocabulary and Medieval Text Types: A Semantic Field Approach," Neuphilologische Mitteilungen," forthcoming. 
${ }^{23}$ The proportions of nouns in the two categories were further subdivided so that the numbers of terms unique to the romance text type could be measured against the distributions across the administrative text types individually. There are 74 terms unique to the wills, 63 terms unique to the sumptuary laws, and 19 terms unique to the petitions.

${ }^{24}$ Definitions are adapted from those found in the glossary of Sylvester et al, ed. Medieval Dress and Textiles in Britain.

${ }^{25}$ Laura Wright, “A Hypothesis on the Structure of Macaronic Business Writing,” in

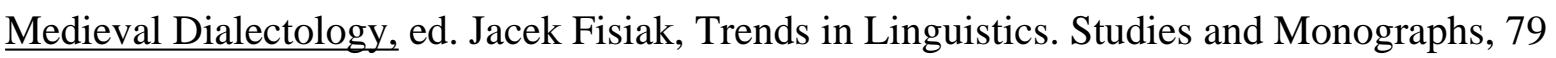
(Berlin: Mouton de Gruyter, 1995), p. 312.

${ }^{26}$ Wright bases her account on that in John Lyons, Semantics (Cambridge: Cambridge Univ. Press, 1977), pp. 291-295. Historical lexicologists have argued for the centrality of semantic relations such as hyponymy and thus for the salience of approaches to the lexicon based on lexical decomposition or componential analysis (see, for example, Dirk Geeraerts, "Cognitive Grammar and the History of Lexical Semantics," in Topics in Cognitive Linguistics, ed. Brygida Rudzka-Ostyn, Current Issues in Linguistic Theory, 50 (Amsterdam and Philadelphia: John Benjamins, 1988), pp. 647-677; Louise Sylvester, Studies in the Lexical Field of Expectation, Costerus New Series, 90 (Amsterdam and Atlanta, GA: Rodopi, 1994); Christian J. Kay, "Historical Semantics and Historical Lexicography: Will the twain ever meet?" in Lexicology, Semantics and Lexicography, ed. Christian J. Kay and Julie Coleman Current Issues in Linguistic Theory, 194 (Amsterdam and Philadelphia: John Benjamins, 2000).

${ }^{27}$ David Sankoff, Pierrette Thibault, and Helene Bérubé, "Semantic Field Variability," in Linguistic Variation: Models and Methods, ed. David Sankoff (New York: Academic Press, 1978), p. 25. See also Sylvester, Studies in the Lexical Field of Expectation, p. 30; Christian Kay, Jane Roberts, Michael Samuels, and Irené Wotherspoon, ed. Historical Thesaurus of the 
Oxford English Dictionary with additional material from A Thesaurus of Old English

(Oxford: Oxford Univ. Press 2009), pp. xviii-xx; Clara Molina, "Historical Dictionary

Definitions Revisited from a Prototype Theoretical Standpoint," Annual Review of Cognitive

Linguistics, 6 (2008), p. 5; Ayumi Miura, Middle English Verbs of Emotion and Impersonal

Constructions: Verb Meaning and Syntax in Diachrony, Oxford Studies in the History of

English (Oxford: Oxford Univ. Press), p. 54

${ }^{28}$ I have followed the practice of the Historical Thesaurus of the Oxford English Dictionary

in demarcating the levels of the semantic hierarchy with numbers of dots (see Kay et al, ed.

Historical Thesaurus of the Oxford English Dictionary. These also offer the visual aid of indenting the headings more as the reader moves down the hierarchy and the terminology more specific. Definitions have been added for clarity, though this function is usually fulfilled by the headings.

${ }^{29}$ In this discussion I have chosen one variant to cite (Middle English terms, where they are found in the text base) but many have a great many variants, sometimes because they appear in different grammatical slots, which may change the spellings, and sometimes because the terms are spelled differently in the different languages in which they appear (or sometimes within a single language).

${ }^{30}$ Terms are given in one of the forms in which they appear in the texts; where the same term appears across a number of languages, the Middle English form is given wherever possible.

${ }^{31}$ J. L. Nevinson, "Civil Costume," in Medieval England, ed. Austin Lane Poole, 2 vols. (Oxford: Clarendon, 1958), p. 305. In the fourteenth century, instead of mantles, which, except for ceremonial occasions became quite rare, men wore short hooded cloaks in the open air.

${ }^{32}$ For a detailed discussion, see Elizabeth Coatsworth, "Cushioning Medieval Life: Domestic Textiles in Anglo-Saxon England," Medieval Clothing and Textiles, 3 (2007), 1-12. 
${ }^{33}$ The database of the Lexis of Cloth and Clothing project offers definitions and citations of the terminology of dress and textiles in use in medieval Britain between c. 700 and 1450. The database may be found at http://lexissearch.arts.manchester.ac.uk/ accessed 08.11.2016 ${ }^{34}$ See L. F. Casson ed. The Romance of Sir Degrevant: A Parallel Text Edition, EETS o.s., 221 (Oxford: Oxford Univ. Press, 1949), p. 129.

${ }^{35}$ See Davenport, "Sir Degrevant and Composite Romance," p. 117.

${ }^{36}$ Sylvester et al., ed. Medieval Dress and Textiles, p. 318.

${ }^{37}$ See the Lexis of Cloth and Clothing database.

${ }^{38}$ Sylvester et al., ed. Medieval Dress and Textiles, p. 46.

${ }^{39}$ Sylvester et al., ed. Medieval Dress and Textiles, p. 48.

${ }^{40}$ We know that russet is not considered a high-end textile from the sumptuary legislation of 1363 which states that 'charetters, charuers, chaceours des charues, bovers, vachers, berchers, porchers, deyes et touz autres gardeins des bestes, batours des bledz et toutes maneres des gentz d'estat de garceon entendantz a husbonderie, et toutes autres gentz qe n'eient quarante solidees de biens, ne de chateux a la value de quarante soldz, ne preignent ne usent nul manere des draps sinoun blanket et russet.' (Also, that carters, ploughmen, drivers of ploughs, oxherds, cowherds, shepherds, swineherds, dairymaids and all other keepers of beasts, threshers of corn and all manner of people of the estate of groom attending to husbandry, and all other people who do not have 40s. in goods, nor chattels to the value of 40s., shall take or wear no manner of cloths except blanket and russet of 12d. for the ell). See Sylvester et al., ed. Medieval Dress and Textiles, p. 206, translation p. 207.

${ }^{41}$ Sylvester et al., ed. Medieval Dress and Textiles, p. 216.

${ }^{42}$ Sylvester et all, ed. Medieval Dress and Textiles, p. 252, translation p. 253.

${ }^{43}$ Sylvester et al., ed. Medieval Dress and Textiles, p 254, translation p. 255.

${ }^{44}$ Sylvester et al., ed. Medieval Dress and Textiles, p. 312. 
${ }^{45}$ Sylvester et al., ed. Medieval Dress and Textiles, p. 24, translation p. 25.

${ }^{46}$ See, for example, the will of Bishop Theodred, dated between 942 and 951 in which he leaves 'min wite massehakele,' 'pere gewele massehakele,' 'pe oper gewele massehakele,' and 'pe red messehakele' (my white chasuble, the yellow chasuble, the other yellow chasuble, and the red chasuble), Sylvester et al., ed. Medieval Dress and Textiles, p. 12, translation p. 13.

${ }^{47}$ Sylvester et al., ed. Medieval Dress and Textiles, p. 32.

${ }^{48}$ Sylvester et al., ed. Medieval Dress and Textiles, p. 342.

${ }^{49}$ Sir Gawain and the Green Knight ed. Tolkien, J. R. R. and E. V. Gordon, Norman Davis, rev. ed. (Oxford: Clarendon, 1967), p. 213.

${ }^{50}$ Sylvester et al., ed. Medieval Dress and Textiles, p. 26, translation p. 27.

${ }^{51}$ Sylvester et al., ed. Medieval Dress and Textiles, p. 30, translation p. 31.

52 Sylvester et al., ed. Medieval Dress and Textiles, p. 44.

${ }^{53}$ Sylvester et al., ed. Medieval Dress and Textiles, p. 204.

${ }^{54}$ Amis and Amiloun, Robert of Cisyle, and Sir Amadace, ed. Edward R. Foster (Kalamazoo, Michigan: Medieval Institute Publications, 2007) at http://d.lib.rochester.edu/teams/text/foster-amis-and-amiloun-introduction accessed 1.2.2017. 